\title{
KEABSAHAN DAN PEMAKAIAN ARAHAN AMALAN DALAM PENTADBIRAN KEHAKIMAN DARI PERSPEKTIF UNDANG-UNDANG SYARIAH DAN SIVIL: SUATU PERBANDINGAN
}

\section{(Validity and Application of Practice Directions in Judicial Administration from the Perspective of Shariah and Civil Law: A Comparison)}

\author{
Zubaidi Sulaiman* \\ hakimmrsgm@gmail.com
}

Ahmad Hidayat Buang

ahidayat@um.edu.my

Jabatan Syariah dan Undang-Undang

Akademi Pengajian Islam Universiti Malaya

Terbit dalam talian (published online): 7 Januari 2021

Sila rujuk: Zubaidi Sulaiman dan Ahmad Hidayat Buang. (2021). Keabsahan dan Pemakaian Arahan Amalan dalam Pentadbiran Kehakiman dari Perspektif Undang-undang Syariah dan Sivil: Suatu Perbandingan. Kanun: Jurnal Undang-undang Malaysia, 33(1), 29-50.

\begin{abstract}
Abstrak
Arahan Amalan telah diperkenalkan di mahkamah sivil sejak tahun 1946 dan di mahkamah syariah bermula pada tahun 2000 hasil daripada adaptasi terhadap Arahan Amalan yang diguna pakai di mahkamah sivil. Artikel ini bertujuan untuk menjelaskan keabsahan dan kedudukan Arahan Amalan serta membandingkannya dari aspek peruntukan undangundang dan pemakaian antara mahkamah syariah dan mahkamah sivil. Kajian yang bersifat kualitatif ini menggunakan kaedah kepustakaan dengan mengaplikasikan instrumen analisis kandungan terhadap peruntukan undang-undang dan laporan kes selain menggunakan kaedah temu bual. Kajian ini mendapati asas pemakaian Arahan Amalan adalah berdasarkan peruntukan undang-undang yang berkuat kuasa. Namun
\end{abstract}


begitu, terdapat perbezaan kedudukan dan pemakaian Arahan Amalan di mahkamah syariah dan mahkamah sivil, iaitu dari sudut punca kuasa, pihak yang berautoriti mengeluarkan Arahan Amalan, penguatkuasaan dan status serta penerbitan Arahan Amalan. Hasil kajian ini diharapkan dapat memberikan panduan dan maklumat berguna kepada pihak Jabatan Kehakiman Syariah Malaysia (JKSM) dan Jabatan Kehakiman Syariah Negeri (JKSN) untuk menilai semula dan meminda undang-undang sedia ada atau membentuk kaedah-kaedah Arahan Amalan untuk memastikan Arahan Amalan yang diguna pakai di mahkamah syariah adalah sah dan tidak boleh dicabar oleh mana-mana pihak.

Kata kunci: Arahan amalan, pentadbiran kehakiman, mahkamah syariah, mahkamah sivil, undang-undang syariah, undang-undang sivil, kaedah arahan amalan

\begin{abstract}
Practice Directions have been introduced in the civil courts since 1946, and an adaptation of these was introduced in the Syariah courts in 2000. This article aims to explain the validity and position of the Practice Directions, as well as to compare these in terms of of legal provisions and application in the Syariah and civil courts. This research is a qualitative study involving library research (analysis of provisions of relevant laws and case reports), supplemented with interviews. It is found that Practice Directions were applied based on the provisions of the laws in force. However, there are differences in the position and application of Practice Directions between the Syariah courts and the civil courts in terms of source of authority, the authorities issuing the Practice Directions, enforcement and status, as well as the publication of Practice Directions. This study may serve as a guideline for Department of Syariah Judiciary Malaysia (JKSM) and State Syariah Judiciary Department (JKSN) to re-evaluate and amend existing laws, or to form methods for Practice Directions for the courts to ensure that the ones used are valid and cannot be challenged by any party.
\end{abstract}

Keywords: Practice Directions, judicial administration, Syariah court, civil court, shariah law, civil law, practice direction methods 


\section{PENDAHULUAN}

Perlembagaan Persekutuan menetapkan bahawa sistem perundangan di Malaysia dilaksanakan melalui dual sistem kehakiman yang unik, ${ }^{1}$ iaitu sistem perundangan sivil yang berasaskan prinsip undang-undang Inggeris dan sistem perundangan syariah yang berasaskan hukum syarak. ${ }^{2}$ Keduadua sistem ini berjalan secara berasingan dan tidak boleh melangkaui bidang kuasa antara satu sama lain. ${ }^{3}$ Sistem perundangan di Malaysia digerakkan melalui dua jenis undang-undang, iaitu undang-undang substantif dan prosedural. Kelicinan pentadbiran undang-undang juga dibantu melalui kewujudan kaedah tertentu setakat mana yang diperakukan dan diwartakan oleh undang-undang itu sendiri. Selain itu, arahan tertentu yang dikenali sebagai Arahan Amalan berkaitan dengan pentadbiran undang-undang dikeluarkan untuk memastikan pentadbiran kehakiman dan proses perbicaraan dapat dijalankan dengan lancar, adil dan sistematik.

\section{DEFINISI ARAHAN AMALAN}

Dalam penggunaan bahasa Melayu, perkataan "arahan" diambil daripada kata dasar "arah" yang membawa maksud sebagai pimpinan dan pengawasan. "Amalan" pula pula diambil daripada perkataan "amal" bermaksud sesuatu yang dilakukan (dilaksanakan, dikerjakan, dsb) sebagai kebiasaan. ${ }^{4}$

Perkataan Arahan Amalan ialah terjemahan daripada perkataan Inggeris dalam undang-undang sivil, iaitu practice direction. Menurut Mohd. Radzali Masrum (2001), ${ }^{5}$ practice membawa maksud amalan, iaitu prosedur yang berkaitan dengan pengendalian prosiding guaman yang sebenar dan tertakluk pada peraturan Kaedah-Kaedah Mahkamah Tinggi. Prosedur itu pula ialah langkah-langkah rasmi yang mesti dilakukan dalam sesuatu tind akan atau lain-lain prosiding guaman, sivil atau jenayah. Direction ialah panduan, iaitu peruntukan dalam statut atau peraturan yang tidak mempunyai kuasa mandatori atau mustahak, tetapi menjelaskan dengan terperinci cara sesuatu perkara itu sepatutnya dilakukan. Sesuatu

1 Perlembagaan Persekutuan 1948 Jadual 9.

2 Wan Arfah Hamzah. (2009). A First Look at the Malaysian Legal System. Shah Alam: Oxford Fajar.

3 Perlembagaan Persekutuan, Perkara 121(1A).

4 Kamus Dewan (Edisi Keempat). (2005). Kuala Lumpur: Dewan Bahasa dan Pustaka, 2005, p.. $42 \& 75$. 
perkara yang dilakukan yang bertentangan dengan peraturan sedemikian tidak semestinya menjadikannya tidak sah.

A Dictionary of Law telah mendefinisikan Arahan Amalan sebagai:

Arahan Amalan ialah pernyataan yang diterbitkan, biasanya dikeluarkan oleh ketua mahkamah atau bahagian yang berkaitan dengannya, yang menunjukkan prosedur yang harus diikuti dalam hal-hal tertentu dari dasar yang dikehendaki oleh mahkamah dalam kes-kes tertentu. ${ }^{6}$

Dictionary of Law pula mendefinisikan Arahan Amalan seperti berikut:

Arahan dan nota, umumnya diterbitkan dalam laporan undang-undang, menunjukkan pandangan para hakim, ketua mahkamah, pendaftar Mahkamah Tinggi berkaitan dengan amalan dan prosedur mahkamah. Arahan amalan tidak mempunyai kuasa statut. ${ }^{7}$

Pengeluaran Arahan Amalan di mahkamah syariah yang bermula pada tahun 2000 merupakan suatu perkara yang boleh dikatakan baharu, hasil daripada adaptasi terhadap arahan amalan yang diguna pakai di mahkamah sivil. ${ }^{8}$ Melalui laman sesawang rasmi Jabatan Kehakiman Syariah Malaysia (JKSM), arahan amalan telah didefinasikan sebagai;

Pernyataan-pernyataan bercetak, yang dikeluarkan oleh Ketua Pengarah/ Ketua Hakim Syarie, menunjukkan prosedur yang perlu diikuti dalam

6 Elizabeth A. Martin (Ed.). (1997). A Dictionary of Law (Fourth Edition). New York: Oxford University Press, hlm. 347: "Practice Direction is published statements, usually issued by the head of the court or division to which they relate, indicating the procedure to be folloed in particular matters of the courts intended policy in certain cases. Definasi yang sama diberikan oleh Kamus Undang-undang (1995) bahawa Arahan Amalan ialah pernyataan bercetak selalunya dikeluarkan oleh ketua Mahkamah atau bahagian yang berkaitan, menunjukkan prosedur yang perlu diikuti dalam hal-hal tertentu atau polisi yang dicadangkan oleh pihak Mahkamah dalam kes-kes tertentu. Tidak seperti peraturan Mahkamah, arahan amalan tidak mempunyai kuasa statut.

7 L.B. Curzon, Dictionary of Law, Kuala Lumpur International Law Book Servises, 2003, hlm. 232-233: "Directions and notes, generally published in the law reports, indicating the views of the judges, masters, registrars of the High Court, relating to matters of practice and procedure of the courts. They do not have any statutory authority."

8 Tun Abdul Hamid Mohamad. (2014). Penambahbaikan dalam Pelaksanaan UndangUndang Harta Pusaka Islam di Malaysia. Seminar Pentadbiran Harta Pusaka Islam Malaysia. Institut Penyelidikan Produk Halal UPM. 
hal-hal tertentu atau polisi yang dicadangkan oleh pihak mahkamah dalam kes-kes tertentu tidak seperti peraturan mahkamah. Arahan Amalan adalah bertujuan sebagai satu arahan pentadbiran.

Menurut Mazni bt Abdul Wahab (2014), ${ }^{9}$ Arahan Amalan JKSM ialah suatu dokumen bertulis yang dikeluarkan oleh Ketua Pengarah JKSM atau Ketua Hakim Syarie berkaitan dengan prosedur atau polisi yang perlu diikuti dan dipatuhi walaupun tidak berstatus undang-undang.

\section{UNDANG-UNDANG, ARAHAN AMALAN DAN PEKELILING}

Undang-undang, Arahan Amalan dan Pekeliling merupakan istilah yang wujud dan digunakan dalam amalan perundangan. Ketiga-tiga istilah ini mempunyai maksud yang berlainan dan memberikan kesan perundangan yang berbeza.

Menurut Kamus Dewan, ${ }^{10}$ undang-undang ialah sesuatu peraturan atau keseluruhan peraturan yang digubal (dibuat) oleh kerajaan dan mesti dipatuhi oleh masyarakat yang berkenaan. Dictionary of $L a w^{11}$ pula mendefinisikan undang-undang seperti yang berikut: "Peraturan yang dikuatkuasakan yang mengatur setiap masyarakat."

Jelas di sini bahawa perkataan undang-undang mempunyai makna yang pelbagai bergantung pada siapa atau pihak mana yang mentafsirkannya mengikut perspektif dan kepentingan masing-masing. Undang-undang adalah untuk keadilan, sesuai dengan keadaan, diterima pakai oleh setiap masyarakat. Undang-undang juga perlu ditafsirkan mengikut perspektif dan kepentingan dalam sesebuah masyarakat. Undang-undang penting bagi mentadbir sesebuah masyarakat. Undang-undang ialah peraturan dalam masyarakatyang telah digubal oleh pemerintah untuk kegunaan individu atau kumpulan bagi memastikan setiap individu itu mematuhi undang-undang. Ketidakpatuhan kepada undang-undang yang telah diterima pakai oleh masyarakat akan menyebabkan tindakan berbentuk hukuman dilaksanakan

9 Mazni Abdul Wahab. (2014). Pemerkasaan Mahkamah Syariah Melalui Pemakaian Arahan Amalan Jabatan Kehakiman Syariah Malaysia (Thesis PhD). Universiti Malaya, hlm. 72

10 Kamus Dewan (Edisi Keempat). (2005). Kuala Lumpur: Dewan Bahasa dan Pustaka p. 1768

11 Elizabeth A.Martin \& Jonathan Law. (2006). Oxford Dictionary of Law (Edisi Keenam). Oxford University Press, hlm. 306: "the enforceable body of rules that govern any societies". 
terhadap mereka. Hal ini berbeza dengan peraturan yang bersifat norma budaya yang diikuti dan diamalkan dalam masyarakat yang tidak berkuat kuasa sebagai undang-undang. Perlanggaran terhadapnya tidak dikenakan denda atau hukuman akan tetapi pelaku mungkin dipandang serong atau mendapat cemuhan daripada masyarakat sekeliling.

Pekeliling pula bermaksud surat rasmi tentang sesuatu perkara yang diedarkan untuk pengetahuan umum (atau untuk tindakan pihak tertentu). ${ }^{12}$ Antara contoh pekeliling yang digunakan di mahkamah sivil termasuklah Pekeliling Ketua Hakim Negara, Pekeliling Ketua Pendaftar Mahkamah Persekutuan dan Pekeliling Pendaftar Mahkamah Tinggi Malaya. Pekeliling, surat pekeliling, arahan amalan, nota amalan dan surat penting, meskipun berbeza nama yang digunakan, memberikan maksud dan implikasi yang sama dalam pentadbiran mahkamah. Di mahkamah syariah pula, antara contoh pekeliling yang digunakan termasuklah Pekeliling Ketua Pengarah/Ketua Hakim Syarie JKSM, Pekeliling Ketua Hakim Syarie Negeri-Negeri, Pekeliling Perkhidmatan, Pekeliling Perbendaharaan dan Pekeliling Ketua Pendaftar. Pekeliling ini biasanya merujuk pengenalan peraturan kerja dan juga penjelasan kepada kekaburan arahan-arahan pentadbiran dan kesamaran sesuatu tugasan harian. Berbanding dengan Arahan Amalan, surat pekeliling mudah dikeluarkan. ${ }^{13}$

\section{ARAHAN AMALAN DARI PERSPEKTIF UNDANG-UNDANG MALAYSIA}

Seperti yang telah dinyatakan, Perlembagaan Persekutuan menetapkan bahawa terdapat dua sistem kehakiman yang dilaksanakan di Malaysia, iaitu Sistem Kehakiman Sivil ${ }^{14}$ dan Sistem Kehakiman Syariah. ${ }^{15}$ Bidang kuasa kedua-dua sistem kehakiman ini telah ditetapkan dan tidak boleh melangkaui bidang kuasa antara satu sama lain selain. Perjalanan pentadbiran kedua-duanya adalah secara berasingan.

Oleh yang demikian, perbincangan Arahan Amalan dari perspektif undang-undang Malaysia hendaklah dilihat dari sisi kedua-dua sistem ini.

12 Kamus Dewan, op. cit, hlm. 719.

13 Sheikh Ghazali Abdul Rahman. (2005). Amalan-Amalan Pentadbiran di Mahkamah Syariah. Jurnal Hukum,. 20(2), 183-184.

14 Perlembagaan Persekutuan, Perkara 121

15 Perlembagaan Persekutuan, Jadual Kesembilan, Senarai II Senarai Negeri 


\section{Perspektif Undang-Undang Sivil}

Halsbury's Law of Malaysia menyatakan bahawa Arahan Amalan yang dikeluarkan oleh mahkamah adalah berkaitan dengan praktik dan amalan sesuatu Mahkamah. ${ }^{16}$ Arahan Amalan dikeluarkan kepada hakim-hakim dan pendaftar mahkamah dan biasanya diterbitkan dalam laporan undang-undang. Berdasarkan laman sesawang rasmi Pejabat Ketua Pendaftar Mahkamah Persekutuan Malaysia, Arahan Amalan ditakrifkan seperti yang berikut:

Arahan Amalan adalah dokumen yang dikeluarkan oleh pihak pentadbiran Mahkamah bertujuan untuk melicinkan urusan pentadbiran di Mahkamah. Ia memberikan penerangan mengenai langkah-langkah serta acara/prosedur yang mesti dipatuhi oleh semua pihak yang terlibat. Arahan Amalan adalah satu surat pekeliling yang tiada kuasa undang-undang sepertimana statut dan undang-undang kes tetapi ianya merupakan satu arahan pentadbiran yang perlu dipatuhi selagi tidak bertentangan dengan mana-mana peruntukkan undang-undang. ${ }^{17}$

Mahkamah sivil telah mengguna pakai Arahan Amalan sejak tahun 1946 lagi. Berdasarkan beberapa definisi sebelum ini didapati bahawa Arahan Amalan tidak mempunyai kuasa statut. Perkara ini telah dinyatakan oleh Mahkamah dalam kes kes Re Langton ${ }^{18}$ bahawa Arahan Amalan merupakan peraturan yang dipraktikkan di Mahkamah tetapi bukanlah suatu undangundang. Pihak Mahkamah berhak untuk mengarahkan pihak-pihak supaya mengikuti Arahan Amalan tersebut secara tegas.

Kedudukan yang sama disahkan oleh Mahkamah Persekutuan dalam kes Jayasankaran lwn $P P^{19}$ apabila menyatakan seperti yang berikut:

"Kami berpendapat bahawa Nota Amalan No. 2 tahun 1960 dimaksudkan untuk tidak lebih dari sekadar arahan untuk tujuan pentadbiran dan tidak dapat ditinggikan menjadi peraturan undang-undang yang mencerminkan kesan dari kehendak seksyen 307."

16 Para 190.1-024, Halsbury's Law of Malaysia, Volume 7(1), Civil Procedure Reissue, Lexis Nexis Sdn. Bhd.

17 Capaian laman web http://www.kehakiman.gov.my/node/1278 pada 23 Mei 2020.

18 [1960] 1 WLR

19 [1983] 1 MLJ 379: "We are of the view that Practice Note No. 2 of 1960 was intended to be no more than direction for administrative purpose and it cannot be exalted into a rule of law reflecting the tue effect of the requirement of section 307 of the code." 
Perkara ini turut ditegaskan oleh mahkamah dalam kes Ooi Bee Tat lwn Tan Ah Chim \& Sons Sdn. Bhd. ${ }^{20}$ apabila mahkamah menyatakan bahawa Arahan Amalan ialah arahan untuk tujuan pentadbiran dan tidak mempunyai kuasa statutori.

Pandangan yang sama juga turut dinyatakan oleh mahkamah dalam kes Chua Choong Yin lwn Tan Boon Bak Trading Sdn Bhd \& Anor. ${ }^{21}$ Namun begitu, pandangan ini tidak diikuti dalam penghakiman kes terkemudian. Dalam kes Megat Najmuddin bin Dato Seri (Dr) Megat Khas lwn Bank Bumiputra (M) Bhd. ${ }^{22}$, hakim Mahkamah Persekutuan menyatakan:

Arahan amalan mempunyai kuasa undang-undang dan perayu telah mematuhinya ....

Dalam kes Kerajaan Negeri Kelantan lwn Petroliam Nasional Berhad dan Kerajaan Malaysia, ${ }^{23}$ Mahkamah menyatakan;

Sementara itu benarlah bahawa arahan amalan tidak mempunyai kuatkuasa undang-undang seperti yang dijelaskan dalam para 12 Jilid 37 Halsbury's Laws of England (Edisi ke-4) ...

Dalam kes OCBC Bank (Malaysia) Bhd lwn Lim Hock Kok \& Anor ${ }^{24}$, mahkamah menegaskan Arahan Amalan yang dikeluarkan secara betul dan sah meskipun digunakan untuk tujuan pentadbiran, namun hendaklah dipatuhi. Malah, jika Arahan Amalan dikesampingkan boleh menimbulkan kekeliruan dan masalah dalam pengurusan kes di mahkamah. Perkara ini ditegaskan oleh Mahkamah dalam kes agak terkini, Country Garden Danga Bay Sdn Bhd lwn Tribunal Tuntutan Pembeli Rumah \& Anor ${ }^{25}$, Mahkamah menyatakan:

20 [1995] 3 MLJ 465

21 [2002] 4 MLJ 145: "Practice Directions are directions for administrative purposes and have no statutory authority."

22 [2002] 1 MLJ 385.

23 [2011] 6 CLJ 649: "While it is true that practice directions do not have the force of law as explained in para 12 of Volume 37 Halsbury's Laws of England (4th Edn).."

24 [2017] 9 CLJ 454

25 [2019] 1 LNS 1693: "So, it can be surmised that as long as the practise directions are not contrary to any written law, they must be complied with. If the practise directions are disregarded willy-nilly, there may arise confusion and even disorder in the management of caseloads in the courts. So to say they are there for mere guidance is quite inaccurate " 
Oleh itu, dapat disimpulkan bahawa selagi arahan amalan tidak bertentangan dengan undang-undang bertulis, ianya mesti dipatuhi. Sekiranya arahan amalan dikesampingkan, mungkin menimbulkan kekeliruan dan bahkan kekacauan dalam pengurusan beban kes di mahkamah. Jadi untuk mengatakan bahawa ianya hanya panduan semata-mata agak tidak tepat.

Berdasarkan beberapa penghakiman mahkamah sivil di atas didapati terdapat dua pandangan berkaitan status dengan Arahan Amalan, iaitu yang pertama Arahan Amalan mempunyai kuasa statutori dan yang kedua Arahan Amalan tidak mempunyai kuasa statutori. Namun demikian, berdasarkan pentakrifan dalam laman sesawang rasmi Pejabat Ketua Pendaftar Mahkamah Persekutuan Malaysia, adalah jelas bahawa arahan amalan ini ialah surat pekeliling yang tiada kuasa undang-undang seperti statut dan undang-undang kes. ${ }^{26}$

\section{Perspektif Undang-Undang Syariah}

Terdapat banyak kes di mahkamah syariah isu yang berkaitan dengan Arahan Amalan ini diulas oleh mahkamah. Antaranya termasuklah kes Muhammad Shariff Leong Abdulah lwn Noraidalena binti Mohd. Najib. ${ }^{27}$ Dalam kes ini hakim bicara menyatakan bahawa Arahan Amalan telah memberikan hak bidang kuasa yang sama seperti juga peruntukan dalam statut. Mahkamah menyatakan:

Kuasa mendengar permohonan interlokutori ini diberi secara eksklusif selain daripada Bahagian XX Bab 1 dan 2 serta seksyen 196 Enakmen Tatacara Mal Mahkamah Syariah (Negeri Sembilan) 2003, Arahan Amalan No. 2 Tahun 2002 juga memberikan hak yang sama ...

Dalam kes Re Nor Farah Ain Shazlin binti Mohd Zamri, ${ }^{28}$ hakim bicara telah merujuk empat Arahan Amalan sebagai panduan dalam prosiding perbicaraan, iaitu Arahan Amalan No. 13 Tahun 2003 mengenai peraturan semakan kes di Mahkamah Tinggi Syariah, Arahan Amalan No.

26 Tun Abdul Hamid Mohamad, op. cit.

27 [2012] JH 34(1) 94

28 [2017] JH 44(1) 136-139 
4 Tahun 2004 tentang tegahan kepada hakim untuk mengubah perintah sendiri, Arahan Amalan No. 5 Tahun 2004 tentang kehadiran pihak-pihak dan wakil semasa prosiding semakan kes mal dan Arahan Amalan No. 3 Tahun 2007 mengenai tatacara permohonan semakan kes oleh hakim.

Dalam kes Timothy John Smith lwn Norliza binti Ali, ${ }^{29}$ Mahkamah Rayuan Syariah telah merujuk Arahan Amalan No. 5 Tahun 2003 dalam penentuan masa untuk membuat tuntutan harta sepencarian. Lebih daripada itu, panel rayuan berpandangan, seksyen 108 Enakmen Undang-Undang Keluarga Islam yang dirujuk oleh pemohon dalam kes ini selayaknya tidak diguna pakai lagi selepas berkuatkuasanya Arahan Amalan tersebut. Arahan Amalan yang sama juga turut dirujuk dalam kes Hamiah binti Yaacob lwn Baitul Mal Majlis Agama Islam Perak. ${ }^{30}$ Mahkamah turut merujuk Arahan Amalan No. 2 Tahun 2006 berkaitan dengan Amalan Sumpah di mahkamah syariah.

Dalam kes Faridah binti Ishak lwn Mohamad Amin bin Ahmad, ${ }^{31}$ hakim bicara telah merujuk Arahan Amalan No. 13 Tahun 2004 untuk menentukan hukuman/perintah yang sesuai kepada Responden dalam kes penghinaan mahkamah. Arahan Amalan yang sama turut dirujuk dalam kes Re Musa Awang, ${ }^{32}$ malah panel rayuan turut membetulkan kekhilafan hakim bicara Mahkamah Tinggi Syariah yang tidak merujuk Arahan Amalan tersebut ketika menjalankan prosiding penghinaan luar mahkamah yang perlu dijalankan secara khusus dan berasingan.

Dalam kes Alek Amran bin Sutan Buyong \& Seorang Lagi 1wn Faridah bt. Johari, ${ }^{33}$ dan kes Zuraimi bin Mustapha lwn Mazliza binti Mat Amin ${ }^{34}$ hakim bicara telah merujuk Arahan Amalan No. 14 Tahun 2006 untuk memperincikan bidang kuasa yang termaktub dalam statut berkenaan permohonan pengesahan nikah poligami.

Seterusnya, dalam kes Norzihani binti Yusof lwn Imran Syakir bin Mohamad, ${ }^{35}$ Mahkamah Rayuan Syariah melahirkan rasa dukacita apabila pemohon tidak merujuk Arahan Amalan No. 12 Tahun 2005 apabila membangkitkan isu sama ada nombor kes baharu perlu diberikan kepada

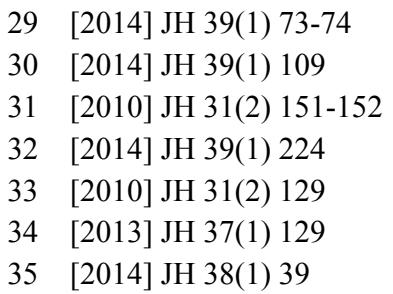


sesuatu kes yang dihidupkan semula setelah dibuang sedangkan isu tersebut telah terang dan jelas dinyatakan dalam Arahan Amalan tersebut. Dalam kes Adenan bin Othman lwn Intan 'Izzati binti Md. Hashim, ${ }^{36}$ hakim bicara telah menjelaskan kehendak sebenar Arahan Amalan No. 13 Tahun 2002 berkaitan dengan pertindihan pendengaran kes merujuk kepada kes yang sama. Arahan Amalan yang sama turut dibangkitkan dan diulas dalam kes Mohd Amizi bin Che Seman lwn Suraya Hani binti Abdullah. ${ }^{37}$ Penjelasan tentang Arahan Amalan No. 1 Tahun 2005 berkaitan dengan prosedur penggantungan pelaksanaan perintah sementara menunggu rayuan telah dijelaskan oleh Mahkamah Rayuan Syariah dalam kes Zainal Abidin bin Mohamed lwn Natasya Gabriel binti Abdullah ${ }^{38}$. Turut diperjelas oleh Mahkamah Rayuan Syariah dalamkesSuip@KanikbinSaniman@Kadad Iwn Salomah binti Saat, ${ }^{39}$ iaitu kehendak Arahan Amalan No. 4 Tahun 2004 tentang mahkamah yang tidak boleh membatalkan keputusannya sendiri dengan mengkhususkan skop Arahan Amalan tersebut kepada kes yang melibatkan fakta yang yang telah dibicarakan di hadapan hakim bukannya fakta yang belum dibicarakan.

Selain menjelaskan kehendak dan maksud sebenar Arahan Amalan yang dirujuk, terdapat juga kes yang telah diperluas skop pemakaian Arahan Amalan dalam prosiding perbicaraan oleh mahkamah. Dalam kes Krisna Hadajani lwn Azian binti Omar, ${ }^{40}$ panel rayuan dalam menjelaskan pemakaian Arahan Amalan No. 12 Tahun 2004 berkaitan dengan tatacara penolakan kes rayuan mal yang tidak mengikut aturan telah memperluas pemakaiannya bukan sahaja terhadap kegagalan pemfailan alasan rayuan dan rekod rayuan tetapi hendaklah terpakai juga terhadap kegagalan memfailkan Afidavit Penyampaian Notis Rayuan.

Ulasan khusus dalam penghakiman berkaitan Arahan Amalan hanya didapati dalam kes Jaafar Hj. Ibrahim lwn Yazelin Mohd. Ghazi. ${ }^{41}$ Hakim bicara menyatakan:

36 [2013] JH 37(1) 76

37 [2015] JH 41(1) 138

38 [2018] JH 46(1) 143

39 [2014] JH 39(1) 29

40 [2013] JH 37(2) 235

41 Kes ini tidak dilaporkan. Kes Mal No. 14700-099-0152-2008 di Mahkamah Tinggi Syariah Wilayah Persekutuan Kuala Lumpur. Lihat Mazni Abdul Wahab, Ahmad Hidayat Buang dan Narizan Abdul Rahman. (2012). Arahan Amalan: Perlaksanaannya di Mahkamah Syariah di Malaysia. The Law Review, 4, 579-599 . 
Arahan Amalan bukan undang-undang tetapi arahan ini tidak sama sekali bertentangan dengan peruntukan undang-undang sedia ada, kerana arahan ini merupakan satu panduan kepada pihak mahkamah dan juga pengamal undang-undang dalam menentukan bidang kuasa berhubung dengan permohonan ini. Arahan Amalan ini telah dibuat oleh mereka yang benar-benar arif dalam hukum hakam dan perundangan semasa dalam membantu mahkamah untuk menegakkan keadilan.

Berdasarkan beberapa kes yang telah diputuskan oleh mahkamah sebelum ini, didapati Arahan Amalan di mahkamah syariah seolah-olah mempunyai kuasa undang-undang. Hal ini dapat dilihat apabila mahkamah merujuk Arahan Amalan untuk menentukan bidang kuasa sesuatu kes itu untuk didengar. ${ }^{42}$

\section{PERBEZAAN PEMAKAIANARAHAN AMALAN DI MAHKAMAH SYARIAH DAN MAHKAMAH SIVIL}

Pemakaian Arahan Amalan di mahkamah syariah yang bermula pada tahun 2000 sememangnya masih baharu berbanding dengan mahkamah sivil yang bermula sejak tahun 1946 lagi. Berdasarkan latar belakang ini dikatakan bahawa pemakaian Arahan Amalan di mahkamah sivil berada pada kedudukan yang lebih mantap dan kukuh berbanding mahkamah syariah. Oleh itu, perbezaan dari aspek pemakaian Arahan Amalan antara kedua-dua mahkamah tersebut dijelaskan seperti yang berikut:

\section{(1) Punca Kuasa Pengeluaran Arahan Amalan}

Arahan Amalan di mahkamah sivil dikeluarkan berdasarkan peruntukan yang ada dalam statut. Misalnya Ketua Hakim Negara berdasarkan Rule 110 of Rule of Federal Court 1995. ${ }^{43}$ Presiden Mahkamah Rayuan di

42 Lihat juga kes Taib bin Omar lwn Shuib bin Omar \& 8 Orang Lagi [2018] JH 46(1) 125), Mohd Khaizam Kamsan lwn Shahrina Sahabuddin [2017] JH 44(1) 70-71, Muhammad Shariff Leong Abdullah lwn Noraidaliena binti Mohd Najib [2012] JH 34(1) 96.

43 PU(A)376/1995. Ia diperuntukkan di bawah nota birau "Directions by Chief Justice," "The Chief Justice may from time to time give such directions with respect to the business in the Registry, as he may consider necessary." Rule 2 mendefinasikan "Registry" sebagai "the Registry of the Federal Court at Kuala Lumpur.". 
bawah Rule 77 of the Rules of the Court of Appeal $1994 .{ }^{44}$ Begitu juga dengan kuasa yang diperoleh oleh Hakim Besar Malaya dan Hakim Besar Sabah dan Sarawak berdasarkan peruntukan Order 92 Rule 3B Of Rules Of Court 2012. ${ }^{45}$ Ringkasnya, ada Arahan Amalan telah dibuat oleh Ketua Hakim Negara, Presiden Mahkamah Rayuan, Hakim Besar Malaya dan Hakim Besar Sabah dan Sarawak. Arahan Amalan yang dikeluarkan melalui Pendaftar Mahkamah Tinggi, Pendaftar Mahkamah Rayuan serta Ketua Pendaftar Mahkamah Persekutuan pula atas arahan hakim-hakim tersebut. ${ }^{46}$ Oleh itu, punca kuasa untuk mengeluarkan Arahan Amalan di mahkamah sivil berpandukan peruntukan yang disebutkan secara jelas dalam statut.

Selain itu, dalam Akta Mahkamah Kehakiman $1964^{47}$ terdapat peruntukan bagi membuat kaedah-kaedah dan amalan di mahkamah tinggi, mahkamah rayuan dan mahkamah persekutuan. Begitu juga dalam Akta Kaedah-Kaedah Mahkamah Rendah $1955^{48}$, Kaedah-Kaedah Mahkamah 2012 telah diwujudkan. Di dalam kaedah tersebut, terdapat 21 peruntukan yang berkaitan dengan Arahan Amalan. Misalnya pada Aturan 12, Kaedah 1. Malah dalam kaedah tersebut juga, terdapat peruntukan khusus bagi mewujudkan Arahan Amalan pada Aturan 92, Kaedah 3B;

Arahan Amalan (A.92, K.3B)

3B. Hakim Besar selepas berunding dengan Ketua Hakim Negara boleh mengeluarkan apa-apa arahan amalan sebagaimana yang difikirkan perlu bagi melaksanakan atau menguatkuasakan peruntukan Kaedah-Kaedah ini dengan lebih baik.

Jelas di sini, kewujudan Arahan Amalan di mahkamah sivil berdasarkan peruntukan ini. Di mahkamah syariah pula, tiada peruntukan yang menyebut secara jelas dan khusus untuk menunjukkan punca kuasanya. Namun begitu, pengeluaran Arahan Amalan berpandukan

44 PU(A) 542/1994. Ia diperuntukkan di bawah birai "Directions by President."

45 PU(A) 205/2012. Order 92

46 Practice Directions 1946-1999. Lihat juga Mazni Abdul Wahab. (2014). Pemerkasaan Mahkamah Syariah Melalui Pemakaian Arahan Amalan Jabatan Kehakiman Syariah Malaysia (Thesis PhD. tidak diterbitkan). Universiti Malaya, hlm. 73.

47 Seksyen 16 Akta Mahkamah Kehakiman 1964 [Akta 91]

48 Seksyen 4 Akta Kaedah-Kaedah Mahkamah Rendah 1955 [Akta 55] 
kepada peruntukan umum seksyen 135 (2) Akta/Enakmen UndangUndang Keluarga Islam:

Mengenai perkara amalan dalam perbicaraan hal ehwal suami isteri yang tidak diperuntukkan dengan nyata dalam Enakmen ini atau dalam apa-apa kaedah-kaedah yang dibuat di bawah Enakmen ini atau dalam Enakmen Pentadbiran, Mahkamah boleh memakai apa-apa amalan dan acara yang difikirkannya wajar bagi mengelakkan ketidakadilan dan bagi menyelesaikan perkara-perkara yang dipersoalkan antara pihak-pihak. ${ }^{49}$

Peruntukan ini memberikan kuasa kepada mahkamah syariah mengguna pakai apa-apa amalan yang difikirkan wajar untuk menjelaskan undangundang yang kabur atau tidak dinyatakan dalam mana-mana peruntukan demi menjaga keadilan kepada pihak-pihak yang bertikai. ${ }^{50}$ Oleh itu, pengeluaran Arahan Amalan adalah sesuatu yang wajar dan memenuhi kehendak peruntukan ini walaupun tidak dinyatakan secara jelas.

Sering kali menjadi polemik sama ada di luar mahkamah atau di dalam mahkamah syariah berkaitan dengan Arahan Amalan yang dikeluarkan oleh JKSM. Perbincangan menjurus kepada sama ada Arahan Amalan telah memenuhi kehendak undang-undang secara sempurna dan adakah Arahan Amalan yang diguna pakai sekarang ini masih boleh disangkal kesahannya. ${ }^{51}$

Seksyen 33 Enakmen Pentadbiran Mahkamah Syariah 1982 (Kelantan) menyatakan;

Seksyen 33. Perkara-perkara tidak diperuntukkan

Mengenai perkara amalan dan acara dalam perbicaraan sivil dan jenayah yang tidak diperuntukkan dengan nyata dalam Enakmen ini atau dalam mana-mana kaedah yang dibuat di bawahnya atau undangundang mengenai acara sivil Syariah dan kanun jenayah Syariah, undang-undang keluarga Islam atau Enakmen Majlis Ugama Islam dan Adat Istiadat Melayu Kelantan 1966, Mahkamah boleh memakai apa-

49 Lihat juga seksyen 137(2) Ordinan Undang-Undang Keluarga Islam (Sarawak) 2001 dan seksyen 153(2) Enakmen Undang-Undang Keluarga Islam (Sabah) 1992.

50 Dato' Abdul Walid Abu Hassan (Pakar Rujuk, JKSM), temu bual pada 6 Februari 2020 jam 10.00 pagi.

51 Mohd Nadzri Haji Abdul Rahman. (2010). Undang-Undang Tatacara Mal Mahkamah Syariah Prinsip dan Amalan. Kuala Lumpur: Anugerah Cekal Sdn. Bhd, hlm. 353. 
apa amalan dan acara Mahkamah sivil yang berkuatkuasa pada masa ini yang difikirkannya wajar bagi mengelakkan ketidakadilan dan bagi menyelesaikan perkara-perkara yang dipersoalkan antara pihak-pihak itu.

\section{Seksyen 34. Kaedah}

Raja boleh melalui pemberitahu dalam Warta membuat kaedah-kaedah bagi menjalankan peruntukan-peruntukan Enakmen ini dari semasa ke semasa tetapi dengan tidak menyentuh keluasan kaedah-kaedah tersebut itu boleh mengadakan:

(a) amalan dan acara dalam semua pembicaraan sivil dan jenayah di bawah Enakmen ini.

Peruntukan seksyen 33 di atas memberi ruang kepada mahkamah syariah di Kelantan untuk memakai apa-apa amalan dan acara yang difikirkan wajar bagi mengelakkan ketidakadilan berlaku. Namun begitu, amalan dan acara yang boleh digunakan ialah amalan mahkamah sivil. Peruntukan yang hampir sama dalam Enakmen Tatacara Mal Mahkamah Syariah di negeri-negeri. Seksyen 247 Enakmen Tatacara Mal Mahkamah Syariah (Kelantan) 2002 menyebut:

\section{Seksyen 247. Kaedah-kaedah}

(1) Jawatankuasa Kaedah-Kaedah Mahkamah Syariah boleh, membuat kaedah-kaedah, yang hendaklah disiarkan dalam Warta, bagi menjalankan peruntukan Enakmen ini, dan khususnya, tetapi tanpa menjejaskan keluasan peruntukan yang terdahulu, kaedah-kaedah itu boleh membuat peru ntukan bagi:

(a) Tatacara dan amalan pejabat pendaftaran Mahkamah Syariah

(b)

(c)

(d)

(e) Perjalanan Mahkamah, bentuk dan kaedah pelaksanaan surat cara dan pelantikan pegawai atau ejen Mahkamah. 
Berdasarkan peruntukan tersebut, Jawatankuasa Kaedah boleh membuat kaedah-kaedah yang berhubungan dengan amalan di pejabat pendaftaran. Arahan Amalan seperti ini sememangnya banyak telah dikeluarkan oleh JKSM. Arahan Amalan yang berbentuk perjalanan mahkamah, bentuk dan kaedah pelaksanaan surat cara juga telah banyak dikeluarkan oleh JKSM. Namun begitu, Arahan Amalan tersebut tidak dikeluarkan menurut kaedah-kaedah seperti yang diperuntukkan di atas. Arahan Amalan yang dikeluarkan dibuat melalui satu keputusan Mesyuarat Arahan Amalan Mahkamah Syariah seluruh Malaysia. Dengan kata lain, hingga kini tiada kaedah atau peraturan yang berkaitan dengan penggubalan Arahan Amalan diwujudkan. ${ }^{52}$

Oleh itu, dapatlah dirumuskan bahawa pemakaian Arahan Amalan di mahkamah sivil mempunyai punca kuasa yang jelas berdasarkan peruntukan dalam statut, manakala di mahkamah syariah pula tiada punca punca kuasa yang jitu melainkan berpandukan pada peruntukan umum dalam undang-undang yang mengakibatkan Arahan Amalan yang diguna pakai adalah tidak sah dan keabsahannya boleh dicabar. Oleh itu, bagi menjadikan Arahan Amalan lebih memenuhi kehendak undang-undang secara sempurna dan agar keabsahan tidak dicabar, maka suatu kaedah seperti yang dinyatakan dalam seksyen 247 Enakmen Tatacara Mal Mahkamah Syariah Negeri-Negeri perlu diwujudkan. Pihak JKSM perlu memainkan peranan untuk mewujudkan kaedah-kaedah Arahan Amalan yang seragam untuk dilaksanakan di semua negeri.

\section{(2) Pihak Berautoriti yang Mengeluarkan Arahan Amalan}

Di mahkamah sivil, Arahan Amalan selain dikeluarkan oleh Ketua Hakim Negara, juga turut dikeluarkan oleh Presiden Mahkamah Rayuan, Hakim Besar Malaya, Hakim Besar Sabah dan Sarawak, Ketua Pendaftar Mahkamah Persekutuan, Pendaftar Mahkamah Tinggi Malaya dan banyak lagi. Di mahkamah syariah Arahan Amalan ini digubal dan dikeluarkan oleh JKSM serta ditandatangani oleh Ketua Pengarah/Ketua Hakim Syarie JKSM untuk diguna pakai oleh mahkamah syariah negeri-negeri. Ketua Hakim Syarie Negeri-negeri akan mengesahkan pemakaian arahan amalan

52 Kecuali yang ada ialah Arahan Amalan No. 8 Tahun 2018, iaitu Tatacara Penerimaan dan Pengendorsan Arahan Amalan dan Arahan Amalan No. 9 Tahun 2018, kehadiran wakil dan bukan ahli dalam Mesyuarat Jawatankuasa Induk Arahan Amalan Mahkamah Syariah, namun keduanya tidak berkait secara langsung dengan tatacara penggubalan dan pembinaan Arahan Amalan. 
yang dibina oleh JKSM di negeri masing-masing berdasarkan peruntukan undang-undang sedia ada. Oleh yang demikian, Arahan Amalan di mahkamah syariah hanya dikeluarkan oleh Ketua Pengarah JKSM/Ketua Hakim Syarie sahaja berbanding di mahkamah sivil yang dikeluarkan oleh pelbagai pihak yang berautoriti.

\section{Penguatkuasaan Arahan Amalan}

Arahan Amalan yang dikeluarkan di Mahkamah Sivil terus berkuat kuasa mulai tarikh kuat kuasa yang dicatatkan pada dokumen Arahan Amalan tersebut. Arahan Amalan yang dikeluarkan oleh Ketua Hakim Negara terpakai di semua mahkamah di Malaysia. Arahan Amalan Presiden Mahkamah Rayuan, Hakim Besar Mahkamah Tinggi Malaya, Hakim Besar Sabah dan Sarawak hendaklah diikuti oleh mahkamah-mahkamah bawahannya. ${ }^{53}$ Di mahkamah syariah pula, meskipun Arahan Amalan telah dikeluarkan oleh JKSM dan ditandatangani oleh Ketua Pengarah/Ketua Hakim Syarie JKSM, namun Arahan Amalan tidak secara automatik berkuat kuasa dan terpakai di seluruh mahkamah syariah negeri-negeri. Pengesahan daripada Ketua Hakim Syarie Negeri diperlukan sebelum Arahan Amalan dikuat kuasa dan dilaksanakan di negeri masing-masing. Namun begitu, Ketua Hakim Syarie negeri tidak terikat untuk mengendorskan atau sebaliknya. ${ }^{54}$ Pengendorsan oleh Ketua Hakim Syarie negeri merupakan titik tolak dan sumber autoriti di mahkamah syariah untuk memastikannya diterima pakai pada peringkat negeri. Jika tidak diendorskan, maka Arahan Amalan tersebut tidak akan terpakai atau berkuat kuasa di negeri tersebut. ${ }^{55}$

\section{(4) Status Arahan Amalan}

Arahan Amalan yang dikeluarkan hanya memberikan garis panduan tentang prosedur. Arahan Amalan tidak mempunyai kuasa untuk menguatkuasakan undang-undang, apatah lagi mewujudkan bidang kuasa mahkamah. Di mahkamah sivil, meskipun Arahan Amalan tidak berstatus undang-undang

53 Mazni Abdul Wahab, 2014, op. cit, p. 75

54 YAA Datuk Mohd Nadzri Haji Abdul Rahman (Ketua Hakim Syarie Negeri Melaka), temu bual pada 7 Februari 2020 jam 3.00 petang.

55 Mazni Abdul Wahab, “Arahan amalan Jabatan Kehakiman Syariah Malaysia di Mahkamah Syariah: Suatu Sorotan Literatur," dalam Journal of Shariah Law Research (2016) vol. 1 (2) 176. Lihat juga Perutusan Y.A.A. Ketua Pengarah/Ketua Hakim Syarie JKSM, iaitu Tan Sri Sheikh Ghazali Hj. Ab. Rahman dalam buku Arahan Amalan Mahkamah Syariah Seluruh Malaysia, 2002. 
tetapi mempunyai kedudukan serta kepentingan tertentu. Arahan Amalan ialah arahan peraturan rasmi yang mesti dipatuhi secara penuh (strictly complied). Sekiranya Arahan Amalan tersebut gagal dipatuhi, boleh mengakibatkan kelewatan perjalanan prosiding kes serta membuang masa mahkamah dan juga pihak-pihak itu sendiri. ${ }^{56}$

Seperti halnya di mahkamah sivil, Arahan Amalan di mahkamah syariah juga tidak berstatus undang-undang. Namun begitu, perlu diingatkan bahawa setelah Arahan Amalan diendorskan penggunaannya oleh Ketua Hakim Syarie negeri untuk pemakaiannya di sesebuah negeri itu, makan Arahan Amalan tersebut merupakan satu arahan sah Ketua Hakim Syarie yang sewajibnya dipatuhi oleh pengamal undangundang negeri tersebut selagi tidak bertentangan dengan hukum syarak. ${ }^{57}$ Meskipun demikian, laporan Jawatankuasa Pemantau Pematuhan Arahan Amalan JKSM menunjukkan atas faktor tertentu, tahap pematuhan Arahan Amalan di mahkamah syariah masih kurang memuaskan. ${ }^{58}$ Mengikut Peraturan-Peraturan Pegawai Awam 1993, ${ }^{59}$ kegagalan seseorang pegawai termasuklah Hakim Syarie atau mana-mana pegawai mahkamah syariah mematuhi penggunaan Arahan Amalan yang telah dikeluarkan dengan sahnya oleh Ketua Hakim Syarie, boleh ditafsirkan sebagai ingkar perintah dan cuai melaksanakan tugasnya serta boleh diambil tindakan. ${ }^{60}$

56 Mazni Abdul Wahab et al., 2012, op.cit, p. 579

57 Tuan Mohd Amran Mat Zain (Hakim Mahkamah Rayuan Syariah, JKSM), temu bual pada 20 Julai 2020 jam 10.00 pagi.

58 Laporan Pemantauan Pematuhan Arahan Amalan 2018 dan 2017 yang disediakan oleh Jawatankuasa Pemantau Pematuhan Arahan Amalan 2018 dan 2017, JKSM. Hasil Pemantauan Tahun 2018 mencatatkan sebanyak 274 ketidakpatuhan terhadap Arahan Amalan yang dikeluarkan oleh JKSM. Selain itu, hanya empat negeri sahaja (Kedah, Sarawak, Melaka dan Wilayah) yang mendapat penarafan pematuhan lima bintang, tujuh negeri mendapat penarafan empat bintang (Selangor, Negeri Sembilan, Perak, Pulau Pinang, Perlis, Terengganu dan Sabah) manakala tiga negeri mendapat penarafan tiga bintang (Kelantan, Johor dan Pahang).

59 Peraturan 4, Peraturan-Peraturan Pegawai Awam (Kelakuan dan Tatatertib) 1993 menyatakan, "seorang pegawai hendaklah pada setiap masa memberikan taat setianya kepada Yang di-Pertuan Agong, Negara dan Kerajaan. Seseorang pegawai tidak boleh ingkar perintah atau berkelakuan dengan apa-apa cara yang boleh ditafsirkan dengan munasabah sebagai ingkar perintah dan cuai dalam melaksanakan tugas-tugasnya."

60 Peraturan 38, Peraturan-Peraturan Pegawai Awam (Kelakuan dan Tatatertib) 1993 menyatakan, "jika seseorang pegawai didapati bersalah atas suatu kesalahan tatatertib, mana-mana satu atau apa-apa gabungan dua atau lebih hukuman yang berikut, bergantung kepada keseriusan kesalahan itu, boleh dikenakan ke atas pegawai itu amaran, denda, lucut hak emolumen, tangguh pergerakan gaji, turun gaji, turun pangkat dan buang kerja." 


\section{(4) Penerbitan Arahan Amalan.}

Arahan Amalan di mahkamah sivil diterbitkan oleh pihak swasta dan mempunyai kompilasi Arahan Amalan dari tahun 1946 hingga 1999. Namun begitu, arahan-arahan untuk tahun 2000 sehingga kini boleh didapati di laman sesawang sahaja. Di mahkamah syariah, Arahan Amalan yang dikeluarkan dimuat naik melalui laman sesawang rasmi JKSM untuk rujukan mana-mana yang pihak yang berkepentingan. Sehingga kini, JKSM belum mengambil inisiatif untuk membuat kompilasi Arahan Amalan dari tahun 2000 hinggalah sekarang. ${ }^{61}$ Sesetengah negeri seperti Kelantan $^{62}$ dan Pahang ${ }^{63}$ mengambil inisiatif sendiri dengan menyediakan kompilasi Arahan Amalan JKSM yang telah diendorskan di negeri tersebut dan membekalkan kompilasi tersebut kepada setiap mahkamah mengikut daerah masing-masing.

\section{KESIMPULAN}

Secara umumnya, pemakaian Arahan Amalan di mahkamah syariah adalah sama dengan yang diamalkan di mahkamah sivil, terutamanya dari segi konsep dan objektif pemakaiannya serta peruntukan undangundang yang mendasarinya. Namun begitu, punca kuasa Arahan Amalan di mahkamah syariah tidak jitu kerana berpandukan pada peruntukan umum undang-undang berbanding dengan pemakaiannya di mahkamah sivil yang disebutkan dengan jelas tentang Arahan Amalan dalam statut. Oleh hal yang demikian, Arahan Amalan yang diamalkan di mahkamah syariah dapat dipertikaikan dan boleh dicabar keabsahannya. Selain berbeza dari sudut punca kuasa, pemakaian Arahan Amalan di mahkamah syariah dan mahkamah sivil juga berbeza dari sudut pihak autoriti yang boleh mengeluarkan Arahan Amalan, penguatkuasaan dan status serta penerbitan Arahan Amalan yang telah dikeluarkan. Bagi memastikan Arahan Amalan di mahkamah syariah adalah sah dan berada pada kedudukan yang kukuh, pihak JKSM dan JKSN perlu mengambil tindakan proaktif ke arah mewujudkan peruntukan undang-undang atau meminda peruntukan umum

61 YAA Datuk Mohd Nadzri Haji Abdul Rahman (Ketua Hakim Syarie Negeri Melaka), Op. Cit

62 YAA Dato' Sri Paduka Raja Haji Daud bin Muhammad (Ketua Hakim Syarie Negeri Kelantan), temu bual pada 20hb Oktober 2019 jam 11.30 pagi.

63 YAA Dato' Sri Haji Abdul Rahman bin Md. Yunos (Ketua Hakim Syarie Negeri Pahang), temu bual pada 19 September 2019 jam 11.00 pagi. 
sedia ada, dengan menyebut secara jelas tentang kedudukan dan pemakaian Arahan Amalan di mahkamah syariah, atau mewujudkan kaedah-kaedah Arahan Amalan seperti yang diamalkan di mahkamah sivil. Usaha ini perlu diberikan perhatian yang sewajarnya memandangkan Arahan Amalan amat signifikan untuk menampung kekurangan yang terdapat dalam Akta/ Enakmen Tatacara Mal dan Jenayah terutamanya bagi menjelaskan prosedur yang kabur. Selain itu, Arahan Amalan dapat membantu penyeragaman peraturan dan tindakan antara mahkamah syariah yang berlainan negeri di negara ini dan mewujudkan setiap mahkamah syariah di Malaysia mempunyai amalan dan standard operasi serta prosiding yang sama. Dengan demikian, pentadbiran mahkamah syariah seluruh negara akan dilonjakkan dan diperkasakan seiring dengan perkembangan yang berlaku di mahkamah sivil. Walau bagaimanapun tidak dapat dinafikan masih banyak perkara yang perlu ditambah baik dan dipertingkatkan, seperti yang pernah dinyatakan oleh mantan Ketua Hakim Syarie JKSM, Tan Sri Sheikh Ghazali Abdul Rahman (2005), perkembangan semasa yang berlaku di mahkamah syariah khususnya pelaksanaan amalan-amalan pentadbiran seperti pengeluaran Arahan Amalan menjadikan amalan pentadbiran yang dilaksanakan di mahkamah syariah tidak ada bezanya jika dibandingkan dengan amalan pentadbiran di mahkamah sivil.

\section{RUJUKAN}

Adenan bin Othman lwn Intan 'Izzati binti Md. Hashim [2013] JH 37(1) 76

Akta Kaedah-Kaedah Mahkamah Rendah 1955 [Akta 55]

Akta Mahkamah Kehakiman 1964 [Akta 91]

Akta Prosedur Jenayah Syariah (Wilayah-Wilayah Persekutuan) 1997 Seksyen 230

Akta Tatacara Mal Mahkamah Syariah (Wilayah-Wilayah Persekutuan) 1998 Seksyen 245

Alek Amran bin Sutan Buyong \& Seorang Lagi lwn Faridah bt. Johari [2010] JH 31(2) 129

Chua Choong Yin lwn Tan Boon Bak Trading Sdn Bhd \& Anor [2002] 4 MLJ 145 Country Garden Danga Bay Sdn Bhd lwn Tribunal Tuntutan Pembeli Rumah \& Anor [2019] 1 LNS 1693

Curzon, LB. (1998). Dictionary of law. Kuala Lumpur: International Law Book Services.

Elizabeth A. Martin, ed. (1997). A Dictionary Of Law, Fourth Edition. New York: Oxford University Press.

Elizabeth A.Martin \& Jonathan Law (2006). Oxford Dictionary of Law, Sixth 
Edition. New York: Oxford University Press.

Enakmen Pentadbiran Mahkamah Syariah (Kelantan)1982

Enakmen Tatacara Jenayah Syariah (Kelantan) 2002

Enakmen Tatacara Jenayah Syariah (Selangor) 2003

Enakmen Tatacara Mal Mahkamah Syariah (Kelantan) 2002

Enakmen Tatacara Mal Mahkamah Syariah (Selangor) 2003

Enakmen Undang-Undang Keluarga Islam (Sabah) 1992

Faridah binti Ishak lwn Mohamad Amin bin Ahmad [2010] JH 31(2) 151-152

Hamiah binti Yaacob lwn Baitul Mal Majlis Agama Islam Perak [2014] JH 39(1) 109

Hamid Sultan bin Abu Backer (1985). Civil procedure in Malaysia and Singapore. Kuala Lumpur: Janab Sdn Bhd.

Wan Arfah Hamzah. (2009). A first look at The Malaysian legal system. Shah Alam: Malaysia Oxford Fajar.

Jayasankaran lwn PP [1983] 1MLJ 379

Kamus Dewan (Edisi Keempat) (2005). Kuala Lumpur: Dewan Bahasa dan Pustaka.

Kerajaan Negeri Kelantan lwn Petroliam Nasional Berhad dan Kerajaan Malaysia [2011] 6 CLJ 649

Krisna Hadajani lwn Azian binti Omar [2013] JH 37(2) 235

Mazni Abdul Wahab (2014). Pemerkasaan mahkamah syariah melalui pemakaian arahan amalan Jabatan Kehakiman Syariah Malaysia (Tesis Doktor Falsafah tidak diterbitkan). Jabatan Syariah dan Undang-Undang, Akademi Pengajian Islam, Universiti Malaya

Mazni Abdul Wahab (2016). Arahan amalan Jabatan Kehakiman Syariah Malaysia di mahkamah syariah: Suatu sorotan literatur. Journal of Shariah Law Research (2016) vol. 1 (2)

Mazni Abdul Wahab, Ahmad Hidayat Buang Buang \& Narizan Abdul Rahman (2012). Arahan amalan: Pelaksanaannya di mahkamah syariah di Malaysia. The Law Review. Sweet \& Maxwell Asia.

Megat Najmuddin bin Dato Seri (Dr) Megat Khas lwn Bank Bumiputra (M) Bhd [2002] 1 MLJ 385

Mohd Amizi bin Che Seman lwn Suraya Hani binti Abdullah [2015] JH 41(1) 138

Mohd Khaizam Kamsan lwn Shahrina Sahabuddin [2017] JH 44(1) 70-71

Mohd Nadzri Haji Abdul Rahman (2010). Undang-Undang Tatacara Mal Mahkamah Syariah prinsip dan amalan. Kuala Lumpur: Anugerah Cekal Sdn. Bhd

Mohd. Radzali Masrum (2001). Maksim dan Ungkapan Undang-undang. Kuala Lumpur: Dewan Bahasa dan Pustaka.

Muhammad Shariff Leong Abdulah lwn Noraidalena binti Mohd. Najib [2012] JH 34(1) 94

Norzihani binti Yusof lwn Imran Syakir bin Mohamad [2014] JH 38(1) 39 
OCBC Bank (Malaysia) Bhd lwn Lim Hock Kok \& Anor [2017] 9 CLJ 454

Ooi Bee Tat lwn Tan Ah Chim \& Sons Sdn. Bhd [1995] 3 MLJ 465

Ordinan Tatacara Jenayah Syariah (Sarawak) 2001

Ordinan Tatacara Mal Syariah (Sarawak) 2001

Ordinan Undang-Undang Keluarga Islam (Sarawak) 2001

Peraturan-Peraturan Pegawai Awam (Kelakuan dan Tatatertib) 1993 Peraturan 4 $\& 38$

Perlembagaan Persekutuan 1948 Jadual 9

Perlembagaan Persekutuan 1948 Perkara 121(1A)

Re Langton [1960] 1 WLR

Re Musa Awang [2014] JH 39(1) 224

Re Nor Farah Ain Shazlin binti Mohd Zamri [2017] JH 44(1) 136-139

Sheikh Ghazali Abdul Rahman (2005). Amalan-amalan pentadbiran di mahkamah syariah. Jurnal Hukum, 20(2).

Suip@Kanik bin Saniman@ Kadad lwn Salomah binti Saat [2014] JH 39(1) 29

Taib bin Omar lwn Shuib bin Omar \& 8 Orang Lagi [2018] JH 46(1) 125)

Timothy John Smith lwn Norliza binti Ali [2014] JH 39(1) 73-74

Tun Abdul Hamid Mohamad. (2014). Penambahbaikan dalam pelaksanaan undang-undang harta pusaka Islam di Malaysia. Seminar Pentdbiran Harta Pusaka Islam Malaysia. Universiti Putra Malaysia: Institut Penyelidikan Produk Halal. Diakses daripada https://tunabdulhamid.me/2014/10/ penambahbaikan-dalam-pelaksanaan-undang-undang-harta-pusaka-islamdi-malaysia/

Wan Arfah Hamzah (2009). A first look at the Malaysian legal system. Shah Alam: Oxford Fajar.

Zainal Abidin bin Mohamed lwn Natasya Gabriel binti Abdullah [2018] JH 46(1) 143.

Zuraimi bin Mustapha lwn Mazliza binti Mat Amin [2013] JH 37(1) 129.

Diperoleh (received): 01 September 2020

Diterima (accepted): 09 Disember 2020 